\title{
THE STREPTOMYCIN CONCENTRATION IN TUBERCULOUS CAVITIES
}

\author{
BY \\ K. D. AROSENIUS, V. O. BJÖRK, AND G. LAURELL \\ From the Departments of Thoracic Surgery and Bacteriology, University Hospital, Uppsala, Sweden
}

(RECEIVED FOR PUbliCATION FEBRUARY 10, 1961)

\section{Controls}

In a preliminary study by Hallén, Björk, and Odeblad (1959) $\mathrm{Na}^{22}, \mathrm{Na}^{24}$, and $\mathrm{Br}^{82}$ were used to demonstrate that the sodium space was the same in tuberculous tissue as in normal lung tissue when measured 24 hours after injection. $\mathrm{Na}^{24}$ was then used to demonstrate the speed of diffusion through the wall of a tuberculous cavity. The aim of this paper is to study if the bigger streptomycin molecules also penetrate into the centre of a tuberculous cavity.

\section{METHOD}

It has not been possible for us to use radioactive isotopes added to the streptomycin molecule. The main objection against this method has been the difficulty in guaranteeing that the radioactivity corresponded to the active streptomycin molecule, and not to an inactive smaller part of the streptomycin molecule. We have therefore chosen a biological test on the streptomycin concentration similar to that used by Turunen, Halonen, and Kosunen (1957).

Our modified diffusion method is as follows: The tuberculous lung tissue to be investigated was sent immediately after extirpation to the Department of Bacteriology. The specimen, usually a tuberculous cavity, was divided into five pieces of equal size. Each of these was placed with its cut surface against the medium on a blood agar plate. Then diffusion was allowed to take place at room temperature for 30 minutes. Varying the diffusion times up to 60 minutes no difference was found after the first 30 minutes of diffusion. A diffusion time of $\mathbf{3 0}$ minutes was therefore chosen. After the diffusion the lung specimens were removed from the plates and inoculated with five different bacteria of known streptomycin resistance. After incubation at $37^{\circ} \mathrm{C}$. for 24 hours the plates were investigated. By the use of different bacteria with known resistance, it was possible to make a qualitative determination of streptomycin as well as a rough quantitative estimation of the drug concentration. As a rule the arrest of the growth of the bacilli was complete and included all of the area where the lung specimen had been placed.
The resistance of the five strains that were used was determined at the same time in each series of investigations. Then the disc method described by Ericsson et al. was used. The bacilli used showed the following resistance: Staph. albus, 0.01-0.05 gamma/ $\mathrm{ml}$., Staph. aureus, 0.1-0.2 gamma/ml., Staph. aureus, 1-4 gamma/ml., Staph. aureus, 25-50 gamma/ml., and Bact. coli, 400 gamma/ml. The resistance given for these strains was constant and varied little within the limits given above.

The medium at the determinations was ordinary agar with $10 \%$ sheep blood.

\section{RESUlts}

The material was first analysed according to the method by which the drugs had been administered.

(1) When $1 \mathrm{~g}$. of streptomycin was given daily (no drug was ever given on the morning of operation), with the last dose the day before surgery, a therapeutic concentration of streptomycin was found within the specimen in 10 cases out of 12. The two exceptions without a demonstrable streptomycin concentration were one with a thick-walled cavity and another with a tuberculoma (Table I).

TABLE I

STREPTOMYCIN IN TUBERCULOUS LUNG TISSUE AFTER DAILY STREPTOMYCIN WITH LAST DOSE DAY BEFORE SURGERY

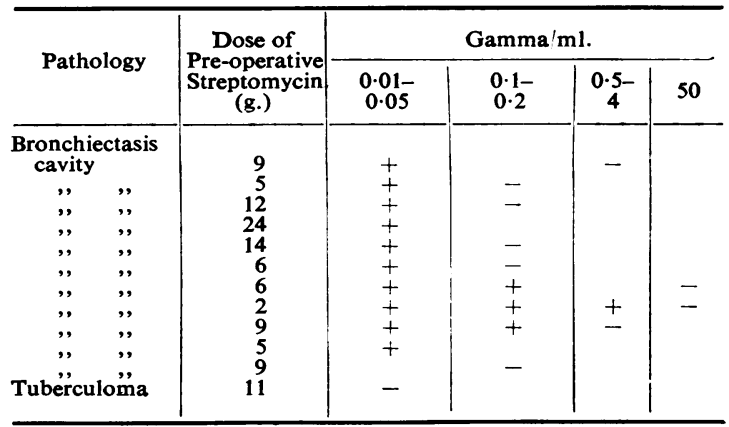

+ , inhibition; - , no inhibition. 
(2) When $1 \mathrm{~g}$. of streptomycin was given every other day, with the last dose the day before operation, streptomycin could be demonstrated in seven specimens out of 12 (Table II).

TABLE II

STREPTOMYCIN IN TUBERCULOUS LUNG TISSUE AFTER STREPTOMYCIN GIVEN ON ALTERNATE DAYS WITH LAST DOSE DAY BEFORE SURGERY

\begin{tabular}{|c|c|c|c|c|c|c|}
\hline \multirow{2}{*}{\multicolumn{2}{|c|}{ Pathology }} & \multirow{2}{*}{$\begin{array}{c}\text { Dose of } \\
\text { Pre-operative } \\
\text { Streptomycin } \\
\text { (g.) }\end{array}$} & \multicolumn{4}{|c|}{ Gamma/ml. } \\
\hline & & & $\begin{array}{c}0.01- \\
0.05\end{array}$ & $\begin{array}{l}0.1- \\
0.2\end{array}$ & $\begin{array}{c}0.5 \\
4\end{array}$ & 50 \\
\hline \multirow{4}{*}{\multicolumn{2}{|c|}{$\begin{array}{l}\text { Bronchiectasis } \\
\text { Empyema wall } \\
\text { Thin-walled } \\
\text { cavity }\end{array}$}} & 9 & + & - &.- & - \\
\hline & & 12 & - & - & - & - \\
\hline & & 6 & + & + & - & - \\
\hline & & 6 & + & + & - & - \\
\hline , , & , & 9 & + & + & - & - \\
\hline ," & , & $\begin{array}{r}7 \\
10\end{array}$ & \pm & - & - & - \\
\hline \multirow{2}{*}{\multicolumn{2}{|c|}{$\begin{array}{c}\text { Thick-walled } \\
\text { cavity }\end{array}$}} & & & & & \\
\hline & & 7 & + & + & - & - \\
\hline ," & , , & 6 & + & - & - & - \\
\hline ,", & , & 8 & - & - & - & - \\
\hline , & , & $\begin{array}{r}16 \\
4\end{array}$ & - & - & - & - \\
\hline , & ", & & & - & & - \\
\hline
\end{tabular}

(3) When 1 g. of streptomycin was given every other day, with the last dose two days before surgery, the drug could only be demonstrated in three cases of seven (Table III).

TABLE III

STREPTOMYCIN IN TUBERCULOUS LUNG TISSUE AFTER STREPTOMYCIN GIVEN ON ALTERNATE DAYS WITH LAST DOSE TWO DAYS BEFORE SURGERY

\begin{tabular}{|c|c|c|c|c|c|}
\hline \multirow{2}{*}{ Pathology } & \multirow{2}{*}{$\begin{array}{c}\text { Dose of } \\
\text { Pre-operative } \\
\text { Streptomycin } \\
\text { (g.) }\end{array}$} & \multicolumn{4}{|c|}{ Gamma/ml. } \\
\hline & & $\begin{array}{l}0.01- \\
0.05\end{array}$ & $\begin{array}{l}0 \cdot 1- \\
0.2\end{array}$ & $0 \cdot 5-$ & 50 \\
\hline Bronchiectasis & 14 & - & - & - & - \\
\hline $\begin{array}{l}\text { cavity } \\
\text { Thick-walled }\end{array}$ & 15 & + & - & - & - \\
\hline cavity & 6 & + & - & - & -- \\
\hline ,", , , & 13 & + & - & - & -- \\
\hline ," & $\begin{array}{l}4 \\
5\end{array}$ & - & - & - & - \\
\hline Tuberculoma & 4 & - & - & $=$ & $\overline{-}$ \\
\hline
\end{tabular}

\section{CONCLUSION}

The pre-operative administration of $1 \mathrm{~g}$. streptomycin every day gives a fairly high incidence of demonstrable streptomycin within the tuberculous lesion, i.e., in 10 of 12 cases. If the drug is administered every other day it could only be demonstrated within the lesion in seven cases of 12 the day after administration and only in three cases of seven two days after.

The material was then analysed according to the radiological findings into thin-walled cavities (Table IV), thick-walled cavities, and tuberculoma (Table V). A significant streptomycin concentration was found in eight of nine thin-walled
TAB LE IV

STREPTOMYCIN IN A THIN-WALLED CAVITY

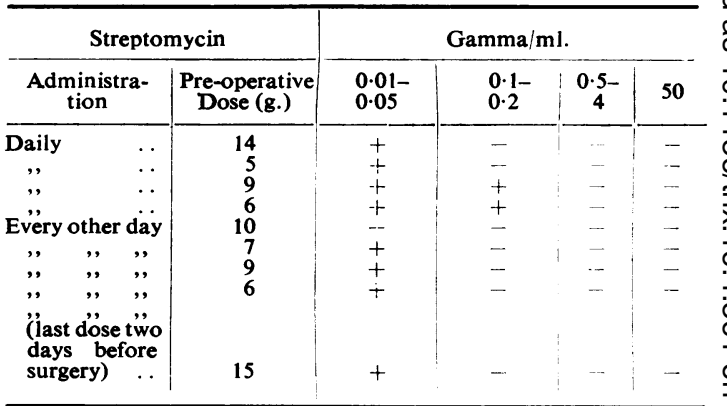

cavities, in seven of 13 thick-walled cavities, and in neither of the tuberculomas. As the distribution of cases with daily treatment and treatment every other day of streptomycin was roughly the same in the three groups a comparison is possible.

A significant streptomycin concentration could be demonstrated more frequently within a thinwalled cavity, i.e., eight times of nine, than within a thick-walled cavity, i.e., seven times of 13 . The drug could not be demonstrated within a tuberculoma.

TABLE $\mathrm{V}$

STREPTOMYCIN IN A THICK-WALLED CAVITY

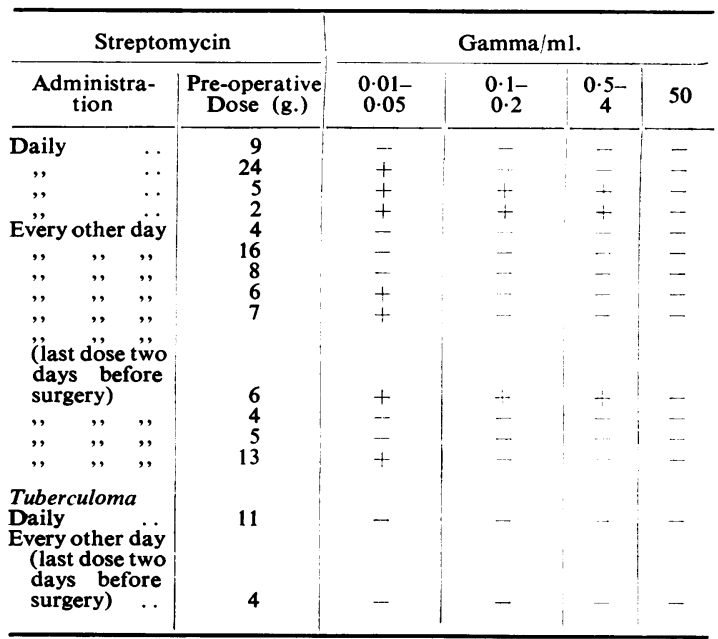

From the tables it can be seen that the amount of streptomycin in the tuberculous lung tissue varied between 0.01 and 1 gamma $/ \mathrm{ml}$. Quantitative determinations showed great variations without significant differences between the groups.

The total dose of streptomycin given before surgery does not seem to influence the concentration of the drug within the specimen. Patients 
with demonstrable streptomycin in the specimen had received on an average $8.9 \mathrm{~g}$. before operation compared with $8.8 \mathrm{~g}$. in patients in whose specimens no streptomycin could be found.

\section{Discussion}

Turunen et al. (1957) could demonstrate a high concentration of active streptomycin in serum, normal lung tissue, normal bronchus, in the wall of a tuberculous cavity, and in its caseous content when $2.5 \mathrm{~g}$. of dihydrostreptomycin was given one and a half hours before operation in six cases.

We have investigated the streptomycin concentration in tuberculous lesions in 31 patients receiving the usual pre-operative treatment with $1 \mathrm{~g}$. daily or every other day. From our results it seems that daily administration of streptomycin is superior to administration every other day. It was more difficult to obtain a demonstrable concentration in a thick-walled cavity compared with a thin-walled cavity. In two cases of tuberculoma a significant concentration of streptomycin was never reached. Therefore we suggest that it is logical to resect tuberculomas and thick-walled tuberculous cavities after a short period of pre-operative streptomycin treatment. This is in agreement with clinical experience. Local continuous administration of streptomycin by a catheter in the lobar pulmonary artery does not seem to be a practical improvement in the administration of streptomycin.

The therapeutic effect is naturally dependent on the sensitivity of the respectively tuberculous bacilli in each case. The concentration demonstrated in our cases would only be sufficient for very sensitive tuberculous bacilli.

\section{SUMMARY}

In 31 cases of pulmonary tuberculosis the streptomycin activity within the cavity has been investigated. Daily administration of $1 \mathrm{~g}$. streptomycin gave superior results compared with administration upon alternate days. Thick-walled cavities did not contain a high streptomycin concentration as often as thin-walled cavities. Two cases with tuberculoma did not contain any demonstrable streptomycin. Therefore we advocate active surgical intervention with resection in thick-walled cavities and tuberculomas after a short period of pre-operative treatment with streptomycin.

\section{REFERENCES}

Hallén, A., Björk, V. O.. and Odeblad, E. (1959). Thorax, 14, 21. Turunen, M., Halonen, P., and Kosunen, T. (1957). Ann. Med. exp. Biol. Fenniae, 35, 95 . 